\title{
Genetic Variability, Heritability, Genetic Advance and Genetic Divergence for Yield and its Contributing Traits in Gladiolus (Gladiolus grandiflorus L.)
}

\author{
Abhishek Kumar, Ashok Kumar* and Abhinav Kumar \\ Department of Floriculture \& Landscape, College of Horticulture \& Forestry \\ Narendra Deva University of Agriculture and Technology, Kumarganj, \\ Faizabad-224 229(UP) India \\ *Corresponding author
}

\section{Keywords \\ Gladiolus, Genetic Variability, \\ Heritability, Genetic Advance, Genetic \\ Divergence, Spike, Yield \\ Article Info \\ Accepted: \\ 07 December 2018 \\ Available Online: \\ 10 January 2019}

\section{A B S T R A C T}

The experiment on ten genotypes of gladiolus (Gladiolus grandiflorus L.) was conducted to work out the genetic variability, heritability, genetic advance and genetic divergence effects of their various attributes on spike yield. The analysis of variance revealed that mean squares due to treatments were highly significant for all characters. The magnitude of phenotypic coefficient of variation was higher than corresponding genotypic coefficient of variation for all the characters. Expected genetic advance expressed as per cent of mean ranged from $4.83 \%$ to $102.96 \%$. The highest of genetic advance as percentage of mean was recorded for number of cormels per plant $(102.96 \%)$ and lowest for number of spikes per plant and number of spikes per hectare (4.83\%). High genetic advance in percent of mean coupled with high heritability was recorded for the characters of number of cormels per plant, weight of cormels per plant, spike yield per hectare, vase life, average weight of spike, duration of flowering, length of spike, days taken for initiation of spike, number of leaves per plant, days taken for complete sprouting, height of plant, percentage of sprouting, number of cormels per plant provide greater scope for further improvement of these traits in advance generations. Genetic advance ranged from 0.066 to 8278.50 . The genetic advance is highest for number of spikes per hectare (q) (8278.50) and lowest number of spikes per plant (0.066). The PCV were higher than GCV for all the characters taken in to consideration. Phenotypic and genotypic coefficient variations were highest for number of cormels per plant (50.04 and 50.11 respectively) and lowest for number of spike per plant (3.44 and 5.04 respectively). Heritability and genetic advance indicate that the additive nature of gene action and reliability of those characters for selection and emerged as ideal traits for improvement through selection. Heritability and genetic advance indicate that the additive nature of gene action and reliability of those characters for selection and emerged as ideal traits for improvement through selection. 


\section{Introduction}

India has a long tradition of floriculture. References to flowers and gardens are found in ancient Sanskrit classics like Rigveda, Ramayana and Mahabharata. The social and economic aspects of flower growing were however, recognized much later. With changing life style and increased urban affluence, floriculture has assumed a definite commercial status in recent times and it has emerged as an important horti.-business venture. In this regard gladiolus has gained much importance as it is the 'Queen of bulbous flowers'. The latin word 'Gladius' means sword and hence, it is often called as 'sword lily' because of the shape of its leaves. Gladiolus was also called 'xiphium' based on the Greek word 'Xiphos' also meaning sword. The gladiolus has a long and noble history. The history of gladiolus cultivation dates back to 2000 years, when some species commonly known as 'corn lily' were grown in parts of Asia Minor. Most of these species are native to Mediterranean region and tropical part of South Africa, particularly the region of the 'Cape of Good Hope'. It was introduced into cultivation towards the end of 16th century. However, in India its cultivation dates back to 19th century as 'Foreigners Manual of Gardening in India' published in 1863, mentions that, Mr. Charles Gray of Coonoor was first person to grow gladiolus in India during nineteen century. First it was thought that only hilly tracts of country were suitable but later on plains were also found suitable for growing it commercially.

Usually plants are unbranched leafy, leaves basal and cauline, sword shaped, less frequently linear or cylindrical. Flowers showy in one sided spikes, irregular, borne in two spathe valves, perianth segments six, united basically into curved, funnel form tube, the upper three segments larger than lower three, stamens 3 , filaments not united, borne below the throat, style branches three entire, fruit, a three valved capsule and the winged seeds are arranged in two rows in each locule. This flower crop possesses a great potential for export market, to European countries especially during winter. It is also a popular decorative plant for use in herbaceous borders, bedding and for growing in pots and bowls. For cut flowers primulinus types are better as more spikes come out from a corm often and may be planted in isolated borders. Other types like grandiflorus and primulinusare much preferred as these do not need staking and also good for beddings. Pixiola (dwarf or miniature ones like colvillea, nanus, byzantius, grandis, tristisetc.) are the daintiest and are preferred for forcing under glass house or for growing in pots and bowls. These also make good cut flowers as they bear smaller spikes to look elegant on the tables. Gladiolus is grown throughout the world and belongs to family 'Iridaceae'. Large scale production of gladiolus cut flowers is seen in USA, Holland, Italy, France, Poland, Bulgaria, Brazil, Australia and also Israel. It stands fourth in the international cut flower trade after carnation, rose and chrysanthemum. The spikes of gladiolus are mainly used for garden and interior decoration and for making bouquets. Gladiolus produce flowers with their beautiful spikes, from October to March in plains and from June to September in hills in India.

The gladiolus is a romantic flower as it signifies remembrance and it also expresses infatuation. The roots of the gladiolus plants were thought to be an aphrodisiac. The upright growth habit of plants lends itself to any manner of floral arrangements, from minimalist Japanese 'Ikebana' and 'Bouquet' bouquets and it excels as a cut flower.

India has suitable agro-climatic conditions for gladiolus cultivation. Cut flowers being grown over an area of 1,460,000 ha, production of $66,671,000$ spikes with productivity of 
45665.07 spikes (2009-2010) in India (NHB Database 2011). In India, it is commercially cultivated in West Bengal, Himachal Pradesh, Sikkim, Karnataka, Uttar Pradesh, Tamil Nadu, Punjab and Delhi. In the eastern states like Tripura, Assam, Manipur, Meghalaya and Nagaland, this flower has established itself as a commercial proposition. There is a sizeable area under gladiolus in Jammu-Kashmir, Andhra Pradesh and Gujarat also. There are over 180 known species of the gladiolus today, but only a few of them are found in most gardens. The orchids like flowers of the Butterfly gladiolus and recently a strain of miniatures have also been introduced. The flowers open from the bottom to up. The flowers may be frilly, ruffled or plain, solid colored or multicolored and they come in every shade and color combination imaginable.

Gladiolus is very rich in its varietal wealth and every year there is an addition of new varieties; hence varietal evaluation becomes necessary to find out suitable variety for a particular region. Improvement of any crop is a continuous process and in gladiolus also there is scope to improve the existing cultivars or genotypes. Since the gladiolus is highly heterozygous, it becomes more essential to evaluate. To create demand for cut flower in the developing urban area of Uttar Pradesh, introduction and popularization is also needed. Any attempt made to encourage cut flower production in the region not only helps the florists and consumers to get fresh and quality cut flowers regularly but also helps the small and marginal farmers in the region to improve their economic condition. Though many genotypes of 'Gladiolus' can be grown in particular agro-climatic region all are not suited for cut flower purpose or for garden display or for exhibition purposes. So, there is a need for evaluation of varieties for particular agro-climatic region of eastern Uttar Pradesh. Faizabad coming under Eastern tract of Uttar
Pradesh, is agro climatically very much suited for growing gladiolus only in winter season of the year. However, performance of new germplasm is also influenced by agro-climatic factors. Hence there is a need to evaluate some of the promising varieties of gladiolus with extended vase life in this area. So that suitable variety could be recommended for commercial cultivation under Eastern Plain Zone of Uttar Pradesh. Considering these points, an investigation was undertaken to study the performance of elite gladiolus varieties identified under Eastern tract of Uttar Pradesh with the following objectives.

\section{Materials and Methods}

The study was designed to work out the status of genetic variability, heritability and genetic advance effects of their various attributes on yield per plant among10 gladiolus genotypes namely Dhanvantry, Jyotsana, Legend, Mohini, Pusa Kiran, Pusa Manmohak, PusaVidushi, Suchitra, Surya Kiran and Urmi at field experiment under present investigation was conducted during Rabi 2015-16 at the Main Experimental Station,Floriculture, N.D.U.A.\& T., Kumarganj, Faizabad (U.P.). Geographically, it is situated in typical saline alkali belt of Indo-gangetic plains of eastern U.P. at 26.47-0 N latitude, $88.120 \mathrm{E}$ longitudes and at an altitude of 113 meter from mean sea level. The region enjoys sub humid and subtropical climate receiving a mean annual rainfall of about $1215 \mathrm{~mm}$ out of which about $85 \%$ is concentrated from mid June to end of September. The winter months are cold and dry and occasional frost occurs during this period. Westerly hot wind starts from the month of March and continues up to onset of monsoon. The experimental materials of studies comprised of 10 gladiolus genotypes. The experiment was laid out in Randomized Block Design. The observation were recorded on 17different traits viz., Days taken for complete sprouting, percentage of 
sprouting, height of plant $(\mathrm{cm})$, number of leaves per plant, days taken for initiation of spike, days taken for opening of first floret, duration of flowering (days), length of spike (cm), number of spikes per plant, vase life (days), average weight of spike (g), spike yield per hectare (q), number of spikes per hectare, number of corms/plant, weight of corm (g), number of cormels/plant and weight of cormels /plant (g). Variability for different characters and heritability in broad sense $\left(h^{2}\right)$ was calculated using the formula suggested by Burton and de Vane (1953). Expected genetic advance $(\overline{\mathrm{Ga}})$ was estimated by the method suggested by Johnson et al., (1955). The genetic divergence among ten genotypes of gladiolus was worked out using Mahalanobis's (1936) D² statistics.

\section{Results and Discussion}

Analysis of variance revealed highly significant difference among the genotypes for all the characters presented in Table 1. Days taken for complete sprouting varied from 22.33 to 32.66. Maximum days taken for complete sprouting was noticed in variety Mohini (32.66) followed by Surya kiran (30.66) and Pusa Manmohak (27.33), while minimum in variety Dhanvantry (22.33) and Pusa Kiran (23.66) and the mean for this character was 26.76. The percentage of sprouting ranged from 100.00 to 75.00 per cent. The maximum percentage of sprouting was noticed in variety Pusa Manmohak (100\%) followed by Pusa Vidushi (95\%) and Surya kiran $(90 \%)$, while minimum in variety Suchitra $(75 \%)$ and the mean for such character was 85.83.(Sidhu and Arora 2000, Rai et.al. 2000 and Basavaraddy 2004.

The height of plant ranged from $66.80 \mathrm{~cm}$ to $48.13 \mathrm{~cm}$. Height was higher in variety Surya Kiran $(66.80 \mathrm{~cm})$ followed by Mohini $(66.33$ $\mathrm{cm})$ and Pusa Kiran $(63.50 \mathrm{~cm})$ while Jyotsana $(48.13 \mathrm{~cm})$ was shortest one and the mean for such character was 58.64. Sidhu and Arora (2000), Raiet al.,(2000) and Basavaraddy (2004). Number of leaves per plant varied from 7.06 to 12.21 . The maximum number of leaves per plant was observed in variety Dhanvantry (12.21) followed by Surya Kiran (10.10) and Suchitra (9.99), while minimum in variety Mohini (4.90). Number of days taken from planting of corms to the initiation of spike varied from 65.00 days to 100.33 days. The earliest initiation of spike was noticed in variety Legend (65.00 days). The maximum number of days taken to initiation of spike was by variety Pusa Manmohak (100.33 days) followed by Surya kiran (99.33 days) and Urmi (98.33 days). Number of days taken from planting of corms to the opening of first floret varied from 77.33 days to 107.00 days. The earliest opening of first floret was noticed in variety Suchitra (77.33 days). The maximum number of days taken to first floret opening was by variety Surya Kiran (107.00 days) followed by Pusa Manmohak (106.33 days) and Urmi (104.66 days). Duration of flowering ranged from 10 days to 21.66 days. The longest duration of flowering was observed for the variety Pusa Manmohak (21.66 days) followed by Pusa Vidushi (18.00 days) and Surya Kiran (17.00 days) and shortest for the variety Suchitra (10.00 days). The length of spike ranged from $50.66 \mathrm{~cm}$ to $116.34 \mathrm{~cm}$. The longest spike was observed for the variety Pusa Vidushi $(116.34 \mathrm{~cm})$ followed by Jyotsana $(101.08 \mathrm{~cm})$ and Pusa Manmohak $(93.00 \mathrm{~cm})$ and shortest for the variety Urmi $(50.66 \mathrm{~cm})$. The number of spikes per plant varied from 1.26 to 1.46 . The number of spikes per plant was maximum in case of variety Suchitra (1.46) followed by Urmi (1.40) and Mohini (1.36), while minimum number of spikes per plant in case of variety Pusa Manmohak (1.26). The vase life of spike varied from 5.00 days to 14.00 days. The variety Suchitra (14.00 days) had maximum vase life in the laboratory when kept in vases with $4 \%$ sucrose solution 
followed by PusaVidushi (13.00 days) and Legend (12.00 days). The variety Dhanvantry (5.00 days) had minimum vase life. Similar results were observed by Singh et al., (2000) and Nagaraju and Parthasarathy (2001). The average weight of spike varied from $52.46 \mathrm{~g}$ to $125.00 \mathrm{~g}$. The highest weight of spike was observed variety Suchitra (125.00g) followed by Surya Kiran, Dhanvantry (87.33 g) and urmi $(84.00 \mathrm{~g})$ and minimum weight of spike variety Mohini (52.46 g). The spike yield per hectare ranged from 89.61 to $228.87 q$.

The highest spike yield was observed variety Suchitra (228.87 q) followed by Dhanvantry (152.76q) and Urmi (147.00q) and lowest spike yield variety Mohini (89.61q). The number of spike per hectare varied from 1.58 to 1.83 lakh. The maximum number of spike was observed variety Suchitra (1.83 lakh) followed by Dhanvantry (1.75 lakh) and Surya Kiran (1.66 lakh) and minimum number of spike variety Pusa Manmohak (1.58 lakh).For the character average weight of spike, spike yield per hectare and number of spike per hectare results are in accordance with Nair and Shiva (2003). Total number of corms produced per plant was recorded highest in variety Jyotsana (2.20) followed by Pusa Manmohak (2.00) and Surya Kiran (1.86) while variety Dhanvantry (1.66) had produced lowest number of corms produced per plant. The weight of the corms per plant varied from $31.40 \mathrm{~g}$ to $42.66 \mathrm{~g}$. The weight of the corms per plant was maximum in variety Mohini $(42.66 \mathrm{~g})$ followed by Jyotsana $(38.73 \mathrm{~g})$ and PusaVidushi (37.80 g) and minimum in variety Surya Kiran (31.40 g) results are in accordance with Seetharamu et al., (2003) and Basavaraddy (2004) shows similar result. The maximum number of cormels produced per plant was recorded in variety Pusa Vidushi (63.86) followed by Pusa Manmohak (46.40) and Legend (36.96). The minimum number of cormels produced per plant was recorded in variety Suchitra (14.93). The weight of the harvested cormels per plant was recorded maximum in variety Pusa Vidushi (12.24 g) followed by Mohini (9.78 g) and Jyotsana $(8.73 \mathrm{~g})$. The minimum weight of cormels per plant was recorded in variety Pusa Kiran (2.73 $\mathrm{g})$. Which is in accordance with the findings of Rai et al., (2000), Kamble (2001), Seetharamu et al., (2003), Choudhary et al., (2011) and Kumar et al., (2012) presented in Table 2.

Estimates with regard to heritability (broad sense) for seventeen characters have been presented in Table 3. The estimates of heritability varied from $46.5 \%$ to $99.7 \%$. The highest heritability estimates in broad sense was observed for the characters number of cormels per plant $(99.7 \%)$ followed by average weight of spike (99.5\%), length of spike (99.4\%), days taken for opening of first floret $(98.8 \%)$, spike yield per hectare (98.4\%), weight of cormels per plant (97.7\%), days taken for initiation of spike (97.5\%), percentage of sprouting $(95.3 \%)$, duration of flowering (93.6\%), height of plant (91.9\%), vase life (90.7\%), weight of corm $(90.6 \%)$, days taken for complete sprouting (85.3\%), number of leaves per plant $(73.9 \%)$, number of corm per plant $(60.7 \%)$. The lowest estimate of heritability in broad sense was noticed for number of spikes per plant and number of spike per hectare (46.5\%). Burton (1953) pointed out that heritability in combination with intensity of selection and amount of variability present in the population influences the genes to be obtained from the selection.

Thus genetic advance is another important selection parameter. The high range of genetic advance was recorded for number of spike per hectare (8.28 thousand), spike yield per hectare (83.18) and average weight of spike (43.31). The medium range of genetic advance was observed for length of spike (42.80), number of cormels per plant (31.80), days taken for initiation of spike (25.80). 
Table.1 Analysis of variance (mean square) for seventeen characters in different varieties of gladiolus

\begin{tabular}{|c|c|c|c|c|}
\hline \multirow[t]{2}{*}{ Sr. no } & Character & Replication & Treatment & Error \\
\hline & d.f. & 2 & 9 & 18 \\
\hline 1 & Days taken for complete Sprouting & 0.23 & $30.15 * *$ & 1.64 \\
\hline 2 & Percentage of Sprouting & 3.23 & $198.6 * *$ & 3.23 \\
\hline 3 & Height of plant $(\mathrm{cm})$ & 2.52 & $119.4 * *$ & 3.40 \\
\hline 4 & Number of leaves per plant & 0.59 & $5.57 * *$ & 0.58 \\
\hline 5 & Days taken for initiation of spike & 1.90 & $486.74 * *$ & 4.12 \\
\hline 6 & Days taken for opening of first floret & 1.23 & $235.12 * *$ & 0.97 \\
\hline 7 & Duration of Flowering(days) & 1.63 & $44.98 * *$ & 1.00 \\
\hline 8 & Length of spike $(\mathrm{cm})$ & 8.73 & $1306^{* *}$ & 2.82 \\
\hline 9 & Number of spike per plant & 0.007 & $0.009 * *$ & 0.002 \\
\hline 10 & Vase life (Days) & 0.43 & $25.48 * *$ & 0.84 \\
\hline 11 & Average weight of spike (g) & 0.68 & $1335.83 * *$ & 2.23 \\
\hline 12 & Spike yield per hectare & 91.12 & $5000.90 * *$ & 27.57 \\
\hline 13 & Number of spikes per hectare & 109375000 & $144097222 * *$ & 39930555 \\
\hline 14 & Number of corms per plant & 0.020 & $0.066^{* *}$ & 0.011 \\
\hline 15 & Weight of corm $(\mathrm{g})$ & 1.009 & $32.22 * *$ & 1.07 \\
\hline 16 & Number of cormels per plant & 0.92 & $717.69 * *$ & 0.647 \\
\hline 17 & Weight of cormels per plant $(\mathrm{g})$ & 0.305 & $20.98 * *$ & 0.162 \\
\hline
\end{tabular}

**Significant at $1 \%$ probability level, Here Mean Sum of Squares of Treatments was significant for all characters. 
Table.2 Mean performances of quantitative characters of gladiolus varieties

\begin{tabular}{|c|c|c|c|c|c|c|c|c|c|c|c|c|c|c|c|c|c|}
\hline Characters & $\begin{array}{l}\text { Days } \\
\text { taken for } \\
\text { complete } \\
\text { sprouting }\end{array}$ & $\begin{array}{c}\% \text { of } \\
\text { sprouting }\end{array}$ & $\begin{array}{l}\text { Height } \\
\text { of plant } \\
\text { (cm) }\end{array}$ & $\begin{array}{c}\text { No. of } \\
\text { leaves } \\
\text { per } \\
\text { plant }\end{array}$ & \begin{tabular}{|c|} 
Days \\
taken for \\
initiation \\
of spike
\end{tabular} & $\begin{array}{c}\text { Days } \\
\text { taken for } \\
\text { opening } \\
\text { of first } \\
\text { floret }\end{array}$ & $\begin{array}{c}\text { Duratio } \\
\text { n of } \\
\text { floweri } \\
\text { ng } \\
\text { (Days) }\end{array}$ & $\begin{array}{l}\text { Length of } \\
\text { spike } \\
\text { (cm) }\end{array}$ & $\begin{array}{c}\text { No. of } \\
\text { spike } \\
\text { per } \\
\text { plant }\end{array}$ & $\begin{array}{l}\text { Vase life } \\
\text { (days) }\end{array}$ & $\begin{array}{l}\text { Av. } \\
\text { weight of } \\
\text { spike (g) }\end{array}$ & $\begin{array}{l}\text { Spike } \\
\text { yield per } \\
\text { hectare } \\
\text { (q) }\end{array}$ & $\begin{array}{l}\text { No. of spikes } \\
\text { per hectare }\end{array}$ & $\begin{array}{c}\text { No. of } \\
\text { corms } \\
\text { per } \\
\text { plant }\end{array}$ & $\begin{array}{c}\text { Weight } \\
\text { of corm } \\
\text { (g) }\end{array}$ & $\begin{array}{l}\text { No. of } \\
\text { cormel } \\
\text { s per } \\
\text { plant } \\
\text { (g) }\end{array}$ & $\begin{array}{l}\text { Weight of } \\
\text { cormels } \\
\text { per plant } \\
\text { (g) }\end{array}$ \\
\hline PusaManmohak & 27.33 & 100.00 & 62.66 & 8.76 & 100.33 & 106.33 & 21.66 & 93.00 & 1.26 & 9.0 & 73.06 & 115.74 & 158333.30 & 2.0 & 35.46 & 46.40 & 8.21 \\
\hline Surya Kiran & 30.66 & 90.00 & 66.80 & 10.10 & 99.33 & 107.00 & 17.00 & 63.42 & 1.33 & 6.0 & 87.33 & 145.54 & 166666.70 & 1.86 & 31.40 & 36.33 & 7.27 \\
\hline PusaVidushi & 27.33 & 95.00 & 60.33 & 8.20 & 70.66 & 93.00 & 18.00 & 116.34 & 1.40 & 13.00 & 79.83 & 139.70 & 175000.00 & 1.80 & 37.80 & 63.86 & 12.24 \\
\hline Jyotsana & 27.33 & 90.00 & 48.13 & 9.73 & 91.66 & 100.33 & 14.33 & 101.08 & 1.33 & 10.33 & 55.23 & 91.66 & 166666.70 & 2.20 & 38.73 & 24.46 & 8.73 \\
\hline Mohini & 32.66 & 85.00 & 66.33 & 7.06 & 81.66 & 97.66 & 11.66 & 63.58 & 1.36 & 8.66 & 52.46 & 89.61 & 170833.30 & 1.73 & 42.66 & 29.00 & 9.78 \\
\hline Legend & 26.00 & 78.33 & 53.46 & 8.85 & 65.00 & 104.66 & 10.00 & 61.16 & 1.33 & 12.00 & 64.33 & 107.31 & 166666.70 & 1.80 & 38.06 & 36.96 & 8.28 \\
\hline PusaKiran & 23.66 & 81.66 & 63.50 & 9.66 & 79.00 & 95.00 & 15.66 & 90.86 & 1.40 & 8.33 & 63.56 & 111.24 & 175000.00 & 1.86 & 32.60 & 18.53 & 2.73 \\
\hline Dhanvantry & 22.33 & 86.66 & 58.06 & 12.21 & 80.33 & 96.00 & 11.33 & 90.95 & 1.40 & 5.00 & 87.33 & 152.76 & 175000.00 & 1.66 & 38.73 & 23.26 & 8.62 \\
\hline Urmi & 26.66 & 76.66 & 52.93 & 8.96 & 98.00 & 104.33 & 12.00 & 50.66 & 1.40 & 8.0 & 84.00 & 147.00 & 175000.00 & 1.80 & 38.20 & 15.13 & 7.98 \\
\hline Suchitra & 23.66 & 75.00 & 54.20 & 9.99 & 73.00 & 77.33 & 10.00 & 82.50 & 1.46 & 14.00 & 125.00 & 228.87 & 183333.30 & 1.86 & 35.46 & 14.93 & 4.42 \\
\hline GM & 26.76 & 85.83 & 58.64 & 9.35 & 83.90 & 98.16 & 14.16 & 81.35 & 1.37 & 9.43 & 77.21 & 132.94 & 1711250.0 & 1.86 & 36.91 & 30.89 & 7.82 \\
\hline CV & 4.78 & 2.09 & 3.14 & 8.19 & 2.41 & 1.00 & 7.07 & 2.06 & 3.69 & 9.72 & 1.93 & 3.95 & 3.69 & 5.84 & 2.80 & 2.60 & 5.14 \\
\hline SEm \pm & 0.73 & 1.03 & 1.06 & 0.44 & 1.17 & 0.56 & 0.57 & 0.97 & 0.02 & 0.52 & 0.86 & 3.03 & 3648.3 & 0.06 & 0.59 & 0.46 & 0.23 \\
\hline CD at $5 \%$ & 2.19 & 3.08 & 3.16 & 1.31 & 3.48 & 1.69 & 1.71 & 2.88 & 0.08 & 1.57 & 2.56 & 9.0 & 10839.68 & 0.18 & 1.77 & 1.39 & 0.69 \\
\hline Minimum & 22.33 & 75.00 & 48.13 & 7.06 & 65.00 & 77.33 & 10.00 & 50.66 & 1.26 & 5.0 & 52.46 & 89.61 & 158333.30 & 1.66 & 31.40 & 14.93 & 2.73 \\
\hline Maximum & 32.66 & 100.00 & 66.80 & 12.21 & 100.33 & 107.00 & 21.66 & 116.34 & 1.46 & 14.00 & 125.00 & 228.87 & 183333.30 & 2.20 & 42.66 & 63.86 & 12.24 \\
\hline
\end{tabular}


Table.3 Genetic parameters of different quantitative characters of gladiolus varieties

\begin{tabular}{|c|c|c|c|c|c|c|c|c|}
\hline \multirow[t]{2}{*}{ Characters } & \multirow{2}{*}{$\begin{array}{c}\text { Grand } \\
\text { mean }\end{array}$} & \multicolumn{2}{|c|}{ Range } & \multirow[t]{2}{*}{ GCV } & \multirow{2}{*}{$\mathbf{P}$} & \multirow{2}{*}{$\begin{array}{c}\text { Heritability } \\
(\text { Broad Sense \%) }\end{array}$} & \multirow{2}{*}{$\begin{array}{l}\text { Genetic Advance } \\
\text { (Ga) }\end{array}$} & \multirow{2}{*}{$\begin{array}{l}\text { Genetic Advance } \\
\text { as percentage of }\end{array}$} \\
\hline & & Min. & Max. & & & & & \\
\hline Days taken for complete & 26.76 & 22.33 & 32.66 & 11.51 & 12. & 85.3 & 5.86 & 21.91 \\
\hline Percentage of sprouting & 85.83 & 75.00 & 100.00 & 9.40 & 9.6 & 95.3 & 16.22 & 18.90 \\
\hline Height of plant(cm) & 58.64 & 48.13 & 66.80 & 10.60 & 11. & 91.9 & 12.28 & 20.94 \\
\hline Number of leaves per plant & 9.35 & 7.06 & 12.21 & 13.77 & $\begin{array}{l}n k \\
16 .\end{array}$ & 73.9 & 2.28 & 24.39 \\
\hline Days taken for initiation of spike & 83.90 & 65.00 & 100.00 & 15.11 & 15. & 97.5 & 25.80 & 30.75 \\
\hline Days taken for opening of first & 98.16 & 77.33 & 107.00 & 9.0 & 9.0 & 98.8 & 18.08 & 18.42 \\
\hline Duration of flowering (Days) & 14.16 & 10.00 & 21.66 & 27.02 & 27. & 93.6 & 7.63 & 53.86 \\
\hline Length of spike (cm) & 81.35 & 50.66 & 116.34 & 25.66 & 25. & 99.4 & 42.80 & 52.61 \\
\hline Number of spikes per plant & 1.37 & 1.26 & 1.46 & 3.44 & 5.0 & 46.5 & 0.066 & 4.83 \\
\hline Vase life (days) & 9.43 & 5.00 & 14.00 & 30.38 & 31. & 90.7 & 5.62 & 59.61 \\
\hline Average weight of spike (g) & 77.21 & 52.46 & 125.00 & 27.30 & 27. & 99.5 & 43.31 & 56.09 \\
\hline Spike yield per hectare (q) & 132.9 & 89.61 & 228.87 & 30.62 & 30. & 98.4 & 83.18 & 62.57 \\
\hline Number of spikes per hectare & 171250 & 15833 & 18333 & 3.44 & 5.0 & 46.5 & 8278.50 & 4.83 \\
\hline Number of corms per plant & 1.86 & 1.66 & 2.20 & 7.26 & 9.3 & 60.7 & 0.217 & 11.65 \\
\hline Weight of corms (g) & 36.91 & 31.40 & 42.66 & 8.73 & 9.1 & 90.6 & 6.31 & 17.12 \\
\hline Number of cormels per plant & 30.89 & 14.93 & 63.86 & 50.04 & 50. & 99.7 & 31.80 & 102.96 \\
\hline Weight of cormels per plant (g) & 7.82 & 2.73 & 12.24 & 33.65 & 34. & 97.7 & 5.36 & 68.53 \\
\hline
\end{tabular}


Table. 4 Clustering pattern of ten genotype of gladiolus on the basis of Mahalanobis $\mathrm{D}^{2}$ statistics:

\begin{tabular}{|l|l|l|l|}
\hline Group k & Number of genotypes & Within SS & Cluster Member \\
\hline $\mathbf{1}$ & 3 & 4022.1870 & Surya kiran(2), Jyotsana(4),Legend(6) \\
\hline $\mathbf{2}$ & 3 & 979.5007 & PusaVidushi (3), PusaKiran (7), Dhanvantry (8) \\
\hline $\mathbf{3}$ & 1 & 0.0000 & Urmi (9) \\
\hline $\mathbf{4}$ & 3 & 494.9642 & PusaManmohak (1), Mohini (5), Suchitra (10) \\
\hline
\end{tabular}

Table.5 Average intra and inter clusters $\mathrm{D}^{2}$ values for four clusters in gladiolus cultivars

\begin{tabular}{|c|c|c|c|c|}
\hline Cluster number & Cluster-1 & Cluster-2 & Cluster-3 & Cluster-4 \\
\hline Cluster-1 & 5088.81 & 27543.16 & 15284.440 & 19249.77 \\
\hline Clucter-2 & & 0.000 & 66062.49 & 78995.64 \\
\hline Cluster-3 & & & 6204.99 & 13161.65 \\
\hline Cluster-4 & & & & 0.00 \\
\hline
\end{tabular}

Table.6 Intra cluster group mean for seventeen characters in gladiolus genotype

\begin{tabular}{|c|c|c|c|c|c|c|c|c|c|c|c|c|c|c|c|c|c|}
\hline Cluster & $\begin{array}{l}\text { Days } \\
\text { taken for } \\
\text { complete } \\
\text { sprouting }\end{array}$ & $\begin{array}{l}\% \text { of } \\
\text { sproutin } \\
\mathrm{g}\end{array}$ & $\begin{array}{l}\text { Height } \\
\text { of plant } \\
(\mathbf{c m})\end{array}$ & $\begin{array}{l}\text { No. of } \\
\text { leaves } \\
\text { per } \\
\text { plant }\end{array}$ & $\begin{array}{l}\text { Days } \\
\text { taken for } \\
\text { initiation } \\
\text { of spike }\end{array}$ & $\begin{array}{l}\text { Days taken } \\
\text { for opening } \\
\text { of first } \\
\text { floret }\end{array}$ & $\begin{array}{l}\text { Duration } \\
\text { of } \\
\text { flowering } \\
\text { (days) }\end{array}$ & $\begin{array}{l}\begin{array}{l}\text { Length } \\
\text { of spike } \\
\text { (cm) }\end{array} \\
\end{array}$ & $\begin{array}{l}\text { No. of } \\
\text { spike } \\
\text { per } \\
\text { plant }\end{array}$ & $\begin{array}{l}\text { Vase } \\
\text { life } \\
\text { (days) }\end{array}$ & $\begin{array}{l}\text { Av. } \\
\text { weight } \\
\text { of spike } \\
\text { (g) }\end{array}$ & $\begin{array}{l}\text { Spike } \\
\text { yield per } \\
\text { hectare } \\
(q)\end{array}$ & $\begin{array}{l}\text { No. of } \\
\text { spikes per } \\
\text { hectare }\end{array}$ & $\begin{array}{l}\text { No. of } \\
\text { corms } \\
\text { per plant }\end{array}$ & $\begin{array}{l}\text { Wt. of } \\
\text { corm } \\
(\mathrm{g})\end{array}$ & $\begin{array}{l}\text { No. of } \\
\text { cormels } \\
\text { per plant }\end{array}$ & $\begin{array}{l}\text { Wt. of } \\
\text { cormels } \\
\text { per plant } \\
\text { (g) }\end{array}$ \\
\hline $\begin{array}{l}1 \\
\text { Cluster }\end{array}$ & 26.75 & 88.33 & 60.11 & 10.01 & 94.50 & 103.41 & 15.50 & 74.22 & 1.35 & 7.00 & 83.93 & 140.26 & $\begin{array}{c}168750.0 \\
0\end{array}$ & 1.83 & 35.95 & 30.28 & 8.02 \\
\hline $\begin{array}{l}2 \\
\text { cluster }\end{array}$ & 23.66 & 75.00 & 54.20 & 9.99 & 73.00 & 77.33 & 10.00 & 82.50 & 1.46 & 14.00 & 125.00 & 228.87 & $\begin{array}{c}183333.3 \\
2\end{array}$ & 1.86 & 35.46 & 14.93 & 4.42 \\
\hline $\begin{array}{l}3 \\
\text { cluster }\end{array}$ & 27.41 & 83.75 & 57.85 & 8.82 & 79.33 & 99.41 & 12.91 & 79.17 & 1.35 & 9.83 & 58.90 & 99.95 & $\begin{array}{c}169791.6 \\
7\end{array}$ & 1.90 & 38.01 & 27.24 & 7.38 \\
\hline $\begin{array}{l}4 \\
\text { cluster }\end{array}$ & 27.33 & 95.00 & 60.33 & 8.20 & 70.66 & 93.00 & 18.00 & 116.34 & 1.40 & 13.00 & 79.83 & 139.70 & $\begin{array}{c}175000.0 \\
0\end{array}$ & 1.80 & 37.80 & 63.86 & 12.24 \\
\hline
\end{tabular}


Table.7 Per cent contribution of seventeen characters towards total genetic divergence in gladiolus

\begin{tabular}{|c|c|c|c|}
\hline S.N. & Source & Times ranked $1^{\text {st }}$ & Contribution (\%) \\
\hline 1. & Days taken for complete sprouting & 0.01 & 0.00 \\
\hline 2. & Percentage of sprouting & 0.01 & 0.00 \\
\hline 3. & Height of plant $(\mathrm{cm})$ & 0.01 & 0.00 \\
\hline 4. & Number of leaves per plant & 0.01 & 0.00 \\
\hline 5. & Days taken for initiation of spike & 0.01 & 0.00 \\
\hline 6. & Days taken for opening of first floret & 0.01 & 0.00 \\
\hline 7. & Duration of flowering (Days) & 0.01 & 0.00 \\
\hline 8. & Length of spike $(\mathrm{cm})$ & 0.01 & 0.00 \\
\hline 9. & Number of spikes per plant & 0.01 & 0.00 \\
\hline 10. & Vase life (days) & 0.01 & 0.00 \\
\hline 11. & Average weight of spike (g) & 0.01 & 0.00 \\
\hline 12. & Spike Yield per hectare (q) & 6.67 & 6.67 \\
\hline 13. & Number of spikes per hectare & 0.01 & 0.00 \\
\hline 14. & Number of corms per plant & 0.01 & 0.00 \\
\hline 15. & Weight of corm (g) & 77.78 & 77.78 \\
\hline 16. & Number of cormels per plant & 11.11 & 11.11 \\
\hline 17. & Weight of cormels per plant (g) & 4.44 & 4.44 \\
\hline
\end{tabular}


Rest of characters showed low to very low genetic advance i.e. days taken for opening of first floret (18.08), percentage of sprouting (16.22), height of plant (12.28), duration of flowering (7.63), weight of corms (6.31), days taken for complete sprouting (5.85), vase life (5.62), weight of cormels per plant (5.36), number of leaves per plant (2.28), number of corms per plant (0.217) and number of spike per plant (0.066). The expected genetic advance was expressed as per cent of mean. It is the unit of measurement of the magnitude of genetic advance. Therefore this cannot be avoided and to facilitate the comparison of genetic improvement in various parameters in per cent of mean. Expected genetic advance expressed as per cent of mean ranged from $4.83 \%$ to $102.96 \%$. The highest genetic advance as percentage of mean was recorded for number of cormels per plant (102.96\%), weight of cormels per plant $(68.53 \%)$, spike yield per hectare $(62.57 \%)$ followed by vase life $(59.61 \%)$, average weight of spike (56.09\%), duration of flowering $(53.86 \%)$, length of spike $(52.61 \%)$, days taken for initiation of spike $(30.75 \%)$, number of leaves per plant $(24.39 \%)$, days taken for complete sprouting (21.91), height of plant (20.94), percentage of sprouting $(18.90 \%)$. Days taken for opening of first floret (18.42), weight of corms $(17.12 \%)$, number of corms per plant (11.65\%), number of spike per plant $(4.83 \%)$, number of spikes per hectare $(4.83 \%)$. presented in Table 3. Similar work was also reported by Kumar (2012) and Maurya (2011). The study of genetic divergence among the 10 varieties of gladiolus was carried out using Mahalanobis $\mathrm{D}^{2}$ statistics. The 10 genotypes were grouped into four different non over lapping cluster (Table 4). Cluster 1,2,4 had highest number of genotypes (3) followed by cluster 3 (1). The distribution pattern of genotypes among different clusters also indicating that there is no geographical parallism in the grouping genotypes indicating that genotype of different geographical origin may group together or vice- versa. The estimates of inter and intra cluster distances represented by $\mathrm{D}^{2}$ values are given in (Table 5). The intra cluster $\mathrm{D}^{2}$ values ranged from 0.000 (cluster 2,4 ) to 6204.99 (cluster 3). The maximum intercluster distance was observed between 2 to 4 (78995.64) which suggested that members of these two clusters were genetically very diverse to each other. Inter- cluster values between cluster 2 and cluster 3 (66062.49), cluster 1 to 2 (27543.16), cluster 1 to 4 (19249.77), cluster 1 to 3 (15284.44), cluster 3 to 4 (13161.65) were very high. The minimum inter- cluster $\mathrm{D}^{2}$ values was recorded in case of cluster 1and 2 (5088.81). The higher inter-cluster distance indicated greater genetic divergence between the varieties of these clusters while lower inter cluster values between the clusters suggested that the genotypes of the clusters were not much genetically diverse from each other. The intra-clusters means for seventeen characters in gladiolus are given Table 6. A perusal of table showed that clusters means for different traits indicated considerable differences between the clusters. Cluster 2 showed maximum mean values for the number of spike per hectare (183333.32), spike yield per hectare (228.87), average weight of spike (125.40), vase life (14.00), number of spike per plant (1.46) and was found for earliest mean values for days taken for complete sprouting (23.66 days), cluster 3 had maximum mean values days taken for complete sprouting (27.41), number of corms per plant (1.90), weight of corm (38.01g), cluster 4 showed mean values for the percentage of sprouting (95.00), height of plant $(60.33 \mathrm{~cm})$, duration of flowering (18.00), length of spike (116.34), number of cormels per plant (63.86), weight of cormels per plant (12.24) and cluster 1 showed mean values for the number of leaves per plant (10.01), days taken for initiation of spike (94.50), days taken for opening of first floret 
(103.41). Cluster 1 showed minimum mean values for the length of spike (74.22), number of spike per plant (1.35), vase life (7.00), number of spike per plant (168750.00), cluster 2 minimum mean values for the days taken for complete sprouting (23.66) percentage of spouting (75.00) height of plant (54.20), days taken for opening of first floret (77.33), duration of flowering (10.00), weight of corm (35.46), number of cormels per plant (14.93), weight of cormels per plant (4.42), cluster 3 minimum mean values for the number of spikes per plant (1.35), average weight of spike (58.90), spike yield per hectare (99.95) and cluster 4 minimum mean values for the number of leaves per plant (8.20 ), days taken for initiation of spike (70.66), number of corms per plant (1.80).Similar finding were also recorded by Patil and Apte (2002), Sheikh and Khanday (2008) and Bhatia and Grewal (2009) for genetic divergence in gladiolus. A perusal of Table 7 showed that some characters zero contribution except spike yield per hectare, weight of corm, number of cormels per plant and weight of cormels per plant very low towards the divergence while weight of corm was found for highest contribution $(77.78 \%)$ followed by number of cormels per plant $(11.11 \%)$ and spike yield per hectare $(6.67 \%)$ for total divergence among the available genotypes of gladiolus.

\section{References}

Basavaraddy, M. (2004). Evaluation of elite hybrids of gladiolus for cut flower production under transition tract of Karnataka. M.Sc. (Ag.) Thesis, University of Agricultural Sciences, Dharwad.

Bhatia, R. and Grewal, H.P.S. (2009). Genetic variability and heritability studies in gladiolus, Indian Agriculturist; 53: 1/2, 1-6. 21.
Burton, G.W. and De Vane, E.H. (1953). Estimating heritability in tall fescue (Festuca arundinacea) from replicated clonal material Agron.J.45:478-481.

Choudhary, M; Moond, S.K.; Kumari, A and Beniwal, B.S. (2011). Evaluation of gladiolus (Gladiolus x hybrids Hort.) varieties for cut flower production under sub humid condition of Rajasthan, Crop Research (Hisar). 4 1(1/3): 123-126.

Johnson, H. W., Robinson, H. F. and Comstock, R. E. (1955). Estimates of genetic and environmental variability in soybean, Agron. J., 47: 477-483

Kamble, B. S. (2001). Evaluation of gladiolus varieties, M.Sc. (Hort.) Thesis, University of Agricultural Sciences, Dharwad.

Kumar, R., Kumar, S. and Yadav, Y.C. (2012). Genetic variability, heritability, genetic advance, correlation coefficient and path analysis in gladiolus. Indian Journal of Horticulture; 69 (3): 369373.

Mahalanobis, P.C. (1936). A statistical study at Chinese head measurements. $J$. Asiatic Soc. Bengal. 25: 301-377.

Maurya, P. K., Kumar, R., Chakraborty, B., Mer, R. and Mishra, D.S. (2011). Genetic variability and correlation studies in Gladiolus hybrid L. under tarai condition of Uttarakhand, Progressive Horticulture, 43 (2): 323327.

NHB Database (2011).

Nagaraju, V. and Parthasarathy, V.A. (2001). Evaluation of gladiolus germplasm at mid hill of Meghalaya, Indian Journal of Horticulture; 58 (3): 269-275.

Nair, S.A. and Shiva, K.N. (2003). Performance of selected gladiolus (Gladiolus floribundus) varieties under bay island conditions. Indian Journal of Agriculture Science; 73 (7): 397-398. 
Patil N N and Apte V B (2002). Genetic divergence in gladiolus. Proc 89th Indian science congress. Pp. 59.

Rai, S.K., Katiyar, R.S. and Singh, S.P. (2000). Prospects of gladiolus crops on sodic wasteland. Proceedings of the National Conference on Gladiolus, January, Pp. 104-106.

Seetharamu, G.K., Kumar, D.P., Mohan, E. and Sridhara Harle, P., (2003). Evaluation of gladiolus varieties under low-cost polyhouse for hill zone. National Symposium on Recent Advances in Indian Floriculture, November 12-14, 89.
Sheikh M Q and Khanday B A (2008). Genetic diversity in gladiolus (Gladiolus hybridus L.). Journal of Ornamental Horticulture; 11: 216-19.

Sidhu, G. S. and Arora, J. S. (2000). Evaluation of gladiolus varieties for summer flower production. Proceeding of the National Conference on Gladiolus, January, Pp. 115- 117.

Singh, K., Singh, P. and Arora, J. S., (2000). Effect of cultivar response, season, stage of harvest and sucrose on keeping quality of gladiolus spikes. Proceeding of the National Conference on Gladiolus, January, Pp. 143-149.

\section{How to cite this article:}

Abhishek Kumar, Ashok Kumar and Abhinav Kumar. 2019. Genetic Variability, Heritability, Genetic Advance and Genetic Divergence for Yield and its Contributing Traits in Gladiolus (Gladiolus grandiflorus L.). Int.J.Curr.Microbiol.App.Sci. 8(01): 689-701.

doi: https://doi.org/10.20546/ijcmas.2019.801.077 